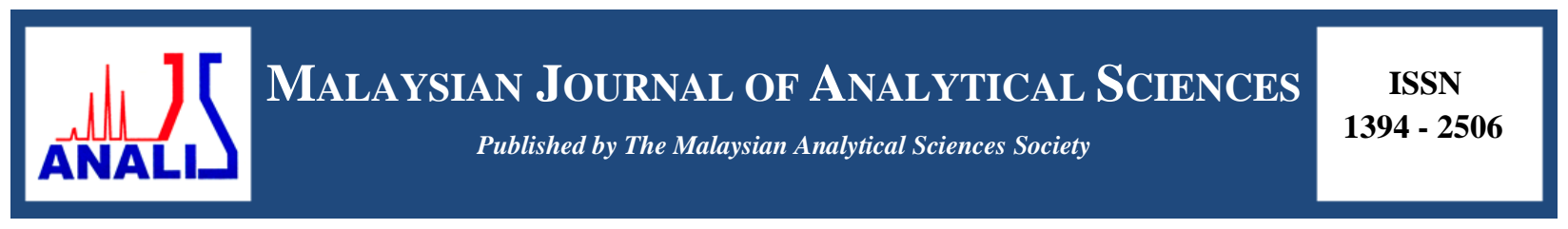

\title{
FABRICATION AND CHARACTERIZATION OF RUBY NANOPARTICLES
}

\author{
(Fabrikasi dan Pencirian Partikel Nano Delima) \\ Wan Aizuddin Wan Razali*, Azman Kasim, Syamsyir Akmal Senawi, Azhan Hashim, Norihan Yahya, \\ Hartini Ahmad Rafaie \\ Faculty of Applied Sciences, \\ Universiti Teknologi MARA Pahang, 26400 Bandar Tun Abdul Razak Jengka, Pahang, Malaysia \\ *Corresponding author: wanaizuddin@pahang.uitm.edu.my
}

Received: 4 December 2016; Accepted: 1 December 2017

\begin{abstract}
Numerous works have been done on finding nanoparticles (NPs) with excellent optical properties. In this work, ruby (chromium doped alumina) nanoparticles have been prepared using femtosecond laser ablation. The synthesized nanoparticles were characterised using dynamic light scattering (DLS), transmission electron microscopy (TEM) and fluorescence microscopy. DLS analysis indicates that the particles size is approximately $52 \mathrm{~nm}$. TEM analysis gives smaller particles size with mean size of 38 nm compared to DLS analysis. Spherical shape of the particles was observed through TEM image. The synthesized NPs showed excellent stability in water with $+55 \mathrm{mV}$ zeta potential value. The most efficient wavelengths to excite the ruby NPs were determined as $405 \mathrm{~nm}$ and $554 \mathrm{~nm}$. The emission peak for the ruby NPs was at $690 \mathrm{~nm}$ which is corresponds to ${ }^{2} \mathrm{E}-{ }^{4} \mathrm{~A}_{2}$ transition. The synthesized ruby NPs can be applied as a potential bioimaging label
\end{abstract}

Keywords: ruby nanoparticles, femtosecond laser ablation, emission, bioimaging

\begin{abstract}
Abstrak
Pelbagai usaha telah dilakukan bagi mencari partikel nano yang mempunyai sifat optik yang baik. Dalam kajian yang dilakukan, partikel nano delima (kromium dop alumina) adalah dihasilkan melalui pelelasan laser femto saat. Pencirian sintesis partikel nano adalah berdasarkan serakan cahaya dinamik (DLS), Mikroskopi elektron terhantar (TEM) dan mikroskopi pendarfluor. Analisis DLS menunjukkan saiz partikel adalah dalam linkungan $52 \mathrm{~nm}$. Analisis TEM menandakan kewujudan saiz partikel lebih kecil dengan saiz purata pada julat $38 \mathrm{~nm}$ berbanding analisis DLS. Bentuk sfera pada partikel-partikel berkenaan dicerap melalui imej TEM. Partikel nano yang dihasilkan memberikan bacaan tahap kestabilan yang amat baik di dalam air pada beza keupayaan zeta $55 \mathrm{mV}$. Panjang gelombang yang cekap bagi mengujakan partikel nano delima adalah sekitar julat $405 \mathrm{~nm}$ dan $554 \mathrm{~nm}$. Puncak sinaran bagi partikel nano delima adalah $690 \mathrm{~nm}$ iaitu mewakili anjakan ${ }^{2} \mathrm{E}-{ }^{4} \mathrm{~A}_{2}$. Partikel nano delima yang dihasilkan berpotensi untuk digunakan bagi tujuan penandaan imbasanbio.
\end{abstract}

Kata kunci: partikel nano delima, pelelasan laser femto saat, sinaran, imbasanbio

\section{Introduction}

The fluorescence properties of ruby or Chromium doped Alumina $\left(\mathrm{Cr}: \mathrm{Al}_{2} \mathrm{O}_{3}\right)$ are very well known after the invention of first ruby laser by T. H. Maiman's in 1960 [1]. The ruby laser consisted of a single crystal rod of synthetic corundum with chromium ions substituted the aluminum ions. The rod was pumped using flashlamp in order to emit a single pulse of coherent and monochromatic radiation. $\mathrm{The}^{\mathrm{Cr}^{3+}}$ ion is very interesting because the ${ }^{2} \mathrm{E}^{-}{ }^{4} \mathrm{~A}_{2}$ emission of $\mathrm{Cr}^{3+}$ is one of the best candidate for transitions in the optical spectroscopy of solids [2, 3] and it also have broad band luminescence properties at room temperature [4]. The two zero-phonon emission lines of bulk 
ruby crystals are centred at 694.3 and $692.9 \mathrm{~nm}$ [5]. Previously, research has predominantly been focused on the properties of bulk ruby [6-10], whilst the properties of ruby in nanoparticles form has received less attention.

Since the development of the nanotechnology, ruby NPs have tremendous potential in photonic application. In nanosize form (known as nano-ruby) new applications have been discovered, due to their interesting properties such as long fluorescence lifetime, high colloidal stability and efficient luminescence [11]. Recently, ruby NPs show promising result to be applied as a fluorescence probe for bioimaging application.

A number of different methods have been investigated in order to produce nanoparticle such as sol gel, electrospraying, spray pyrolysis, reduction methods, chemical vapor deposition (CVD), and ball milling [12-17]. Nevertheless, laser ablation method attracts more attention since it can generate of nanoparticle colloids with outstanding purity compared to the conventional manufacturing routes [18]. In this research, a colloidal suspension of ruby NPs was prepared using femtosecond laser ablation. The nanoparticles size, zeta potential and luminescence properties of produced ruby NPs were analyzed using DLS, TEM and fluorescence spectroscopy.

\section{Materials and Methods}

A ruby crystal with dimension of $5 \mathrm{~mm} \times 5 \mathrm{~mm} \times 2 \mathrm{~mm}$ was ablated using femtosecond laser with $300 \mathrm{~mJ}$ power, $100 \mathrm{fs}$ pulse duration with $1 \mathrm{kHz}$ repetition rate. The beam spot was calculated using gaussian function derivation method and estimated to be approximately $100 \mu \mathrm{m}$. The laser fluence of the focused laser beam is $3 \mathrm{~J} / \mathrm{cm}^{2}$. The ablation procedure was done 1 hour per session in atmospheric environment and the particles were collected in distilled water. The laser scanning was set at $4 \mathrm{~mm} / \mathrm{s}$ velocity and $4 \mathrm{~mm} / \mathrm{s}^{2}$ acceleration. The target was moved during the ablation process in order to have fresh surface during laser ablation. The collected colloidal solution was centrifuged at $2000 \mathrm{rcf}$ in 15 minutes in order to force larger particles to settle at the bottom of the tube. The entire upper section (the supernatant) was then collected.

Dynamic Light Scattering (DLS) analysis was used to determine the size distribution and zeta potential of the nanoparticles using a Malvern Nano ZS. The upper section was collected for further analysis. Transmission Electron Microscopy (TEM) analysis was performed using Philips CM10 to analyse the particles size and shape Fluorolog system from Jobin-Yvon-Horiba with $450 \mathrm{~W}$ Xe lamp excitation was employed for spectroscopic measurements. All data were collected at room temperature.

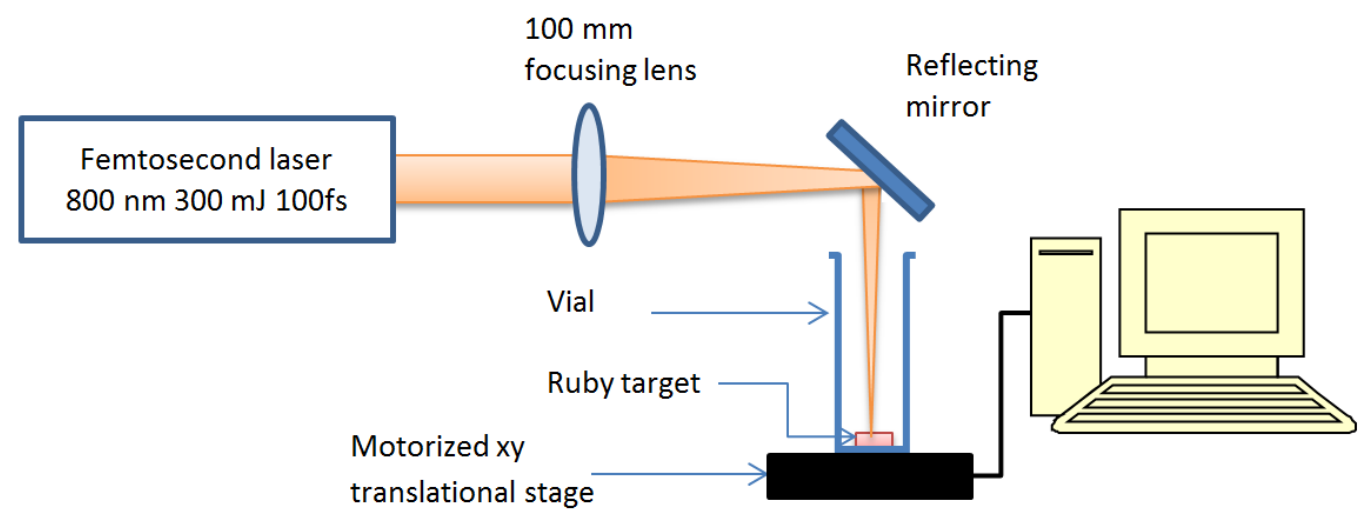




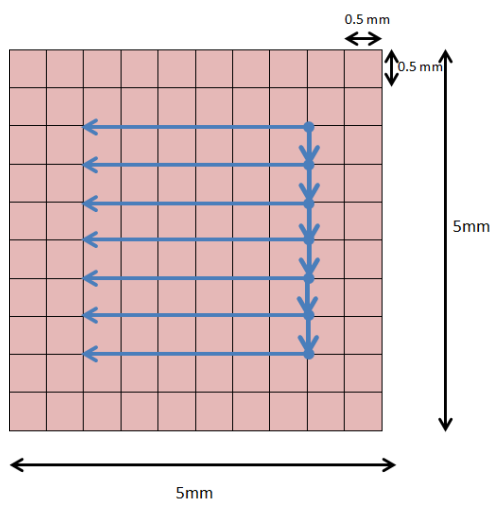

Figure 1. Schematics of experimental setup for laser ablation. Lower part describes the scanning track on ruby crystal surface

\section{Results and Discussion}

Initial investigations using the zeta sizer (see Figure 2a) shows that the size of the ruby NPs in term of hydrodynamics diameter was distributed from $50 \mathrm{~nm}$ to $120 \mathrm{~nm}$ centred at $52 \mathrm{~nm}$. Smaller particles have also been observed which indicate the wide distribution in the size of the particles. Further centrifugation was done in order to fractionize the size of the particles. The particles can be considered as stable, when zeta potential value higher than $+30 \mathrm{mV}$ or lower than $-30 \mathrm{mV}$ [19]. In our work, the zeta potential of produced nanoparticles is $+55 \mathrm{mV}$ (Figure $2 \mathrm{~b}$ ), which indicates excellent stability in water.

Initial investigations using the zeta sizer (see Figure 2a) shows that the size of the ruby NPs in term of hydrodynamics diameter was distributed from $50 \mathrm{~nm}$ to $120 \mathrm{~nm}$ centred at $52 \mathrm{~nm}$. Smaller particles have also been observed which indicate the wide distribution in the size of the particles. Further centrifugation was done in order to fractionize the size of the particles. The particles can be considered as stable, when zeta potential value higher than $+30 \mathrm{mV}$ or lower than $-30 \mathrm{mV}$ [19]. In our work, the zeta potential of produced nanoparticles is $+55 \mathrm{mV}$ (Figure $2 \mathrm{~b}$ ), which indicates excellent stability in water.

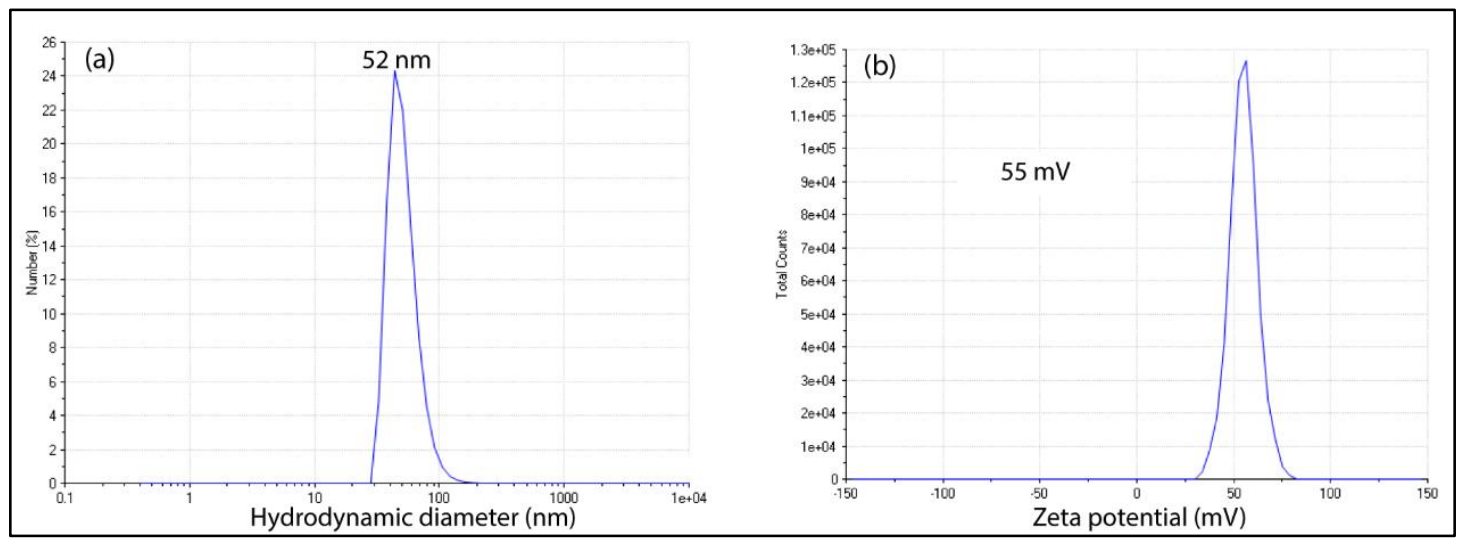

Figure 2. (a) DLS analysis for size distribution and (b) zeta potential of ruby NPs

The particles size and shape of the sample before and after centrifugation process was characterized by TEM. Figure 3 displays the TEM image after the centrifugation process. It can be seen that, more spherical ruby NPs were obtained after undergoing centrifugation process compared to those obtain without undergoing the centrifugation process. The formed nanoparticles disperse well in the solution and does not show any particle aggregation. Further analysis was done using histogram of particle distribution from TEM image as shown in Figure 4. The histogram 
shows that the mean particle size is about $38 \mathrm{~nm}$ compared to DLS analysis with value of $52 \mathrm{~nm}$. Small amount (approximately $10 \%$ ) of particles between $10-27 \mathrm{~nm}$ also have been observed.
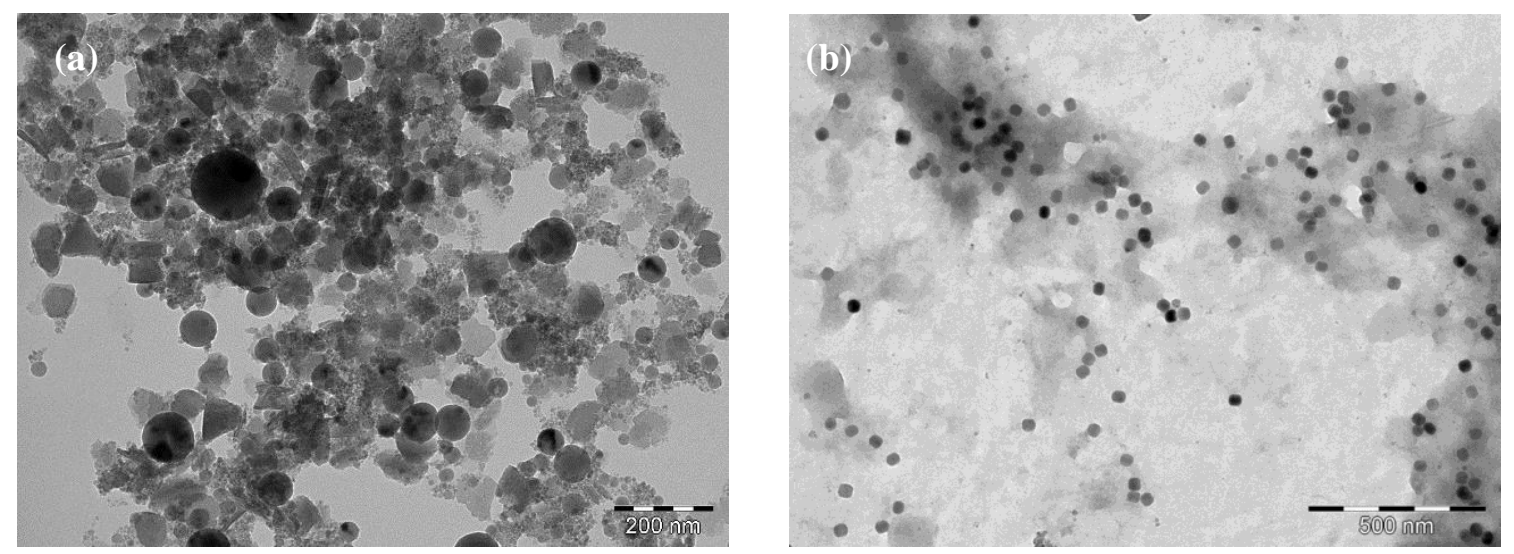

Figure 3. TEM image of ruby NPs before and after centrifugation

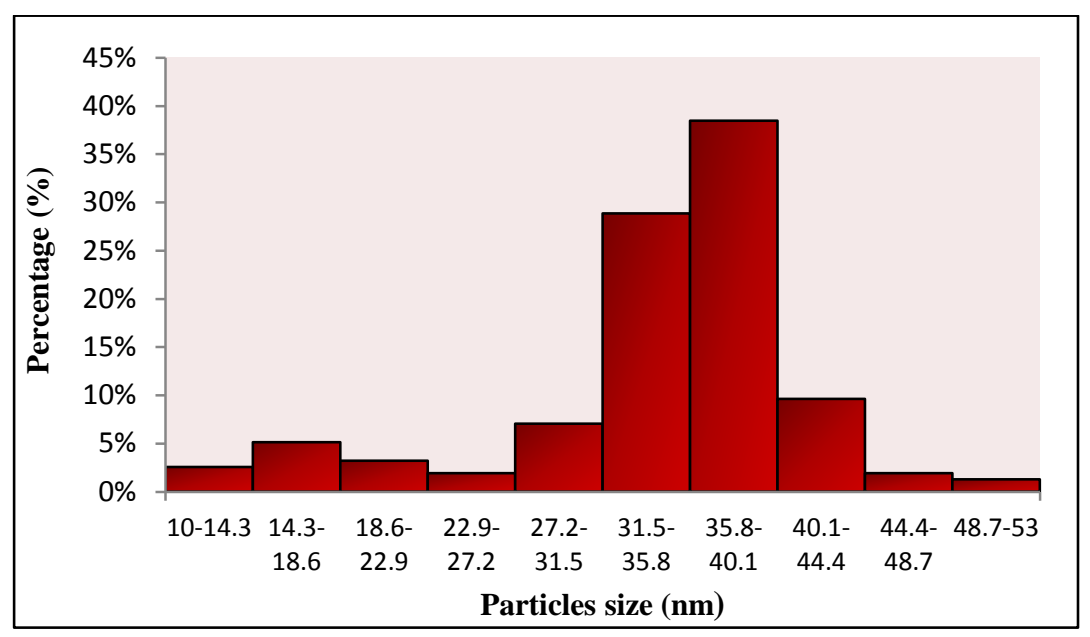

Figure 4. Histogram of particles size distribution from TEM image

Excitation spectrum analysis was carried out in order to determine the optimum excitation wavelength to excite the ruby NPs. As shown in Figure 5, two broad bands centred at $403 \mathrm{~nm}$ and $554 \mathrm{~nm}$ was detected. These peaks were correspond to the spin-allowed ${ }^{4} \mathrm{~A}_{2}\left({ }^{4} \mathrm{~F}\right)-{ }^{4} \mathrm{~T}_{1}$ and ${ }^{4} \mathrm{~A}_{2}\left({ }^{4} \mathrm{~F}\right)-{ }^{4} \mathrm{~T}_{2}$ transitions [2, 19]. Peak at 403 nm shows higher intensity compared to peak at $554 \mathrm{~nm}$, results in good excitation for the ruby NPs.

Figure 6 shows the emission spectra of the ruby NPs disperse in distilled water excited with $403 \mathrm{~nm}$ and $553 \mathrm{~nm}$. Distilled water without ruby particles excited at $403 \mathrm{~nm}$ also been included as a reference. From the emission spectrum analysis for ruby NPs, the peak at $691.11 \mathrm{~nm}$ is observed which can be attributed to the transition of $\bar{E} \rightarrow{ }^{4} \mathrm{~A}_{2}$ and $2 \bar{A} \rightarrow{ }^{4} \mathrm{~A}_{2}$. However, the $\mathrm{R}_{1}$ and $\mathrm{R}_{2}$ lines cannot be seen here, this is could be due low resolution of spectrometer. The intensity of the emission spectrum excitation at $554 \mathrm{~nm}$ is lower compare to spectrum excitation at $405 \mathrm{~nm}$ due lower excitation spectra. There are also two less intensive and partially overlapped peaks at $671 \mathrm{~nm}$ and $710 \mathrm{~nm}$ which could be corresponding to N-lines (zero-phonon lines) related to a coupling between $\mathrm{Cr}^{3+}$ state $^{3}$ and lattice defects and to $\mathrm{Cr}^{3+}-\mathrm{Cr}^{3+}$ pair interactions [4]. 


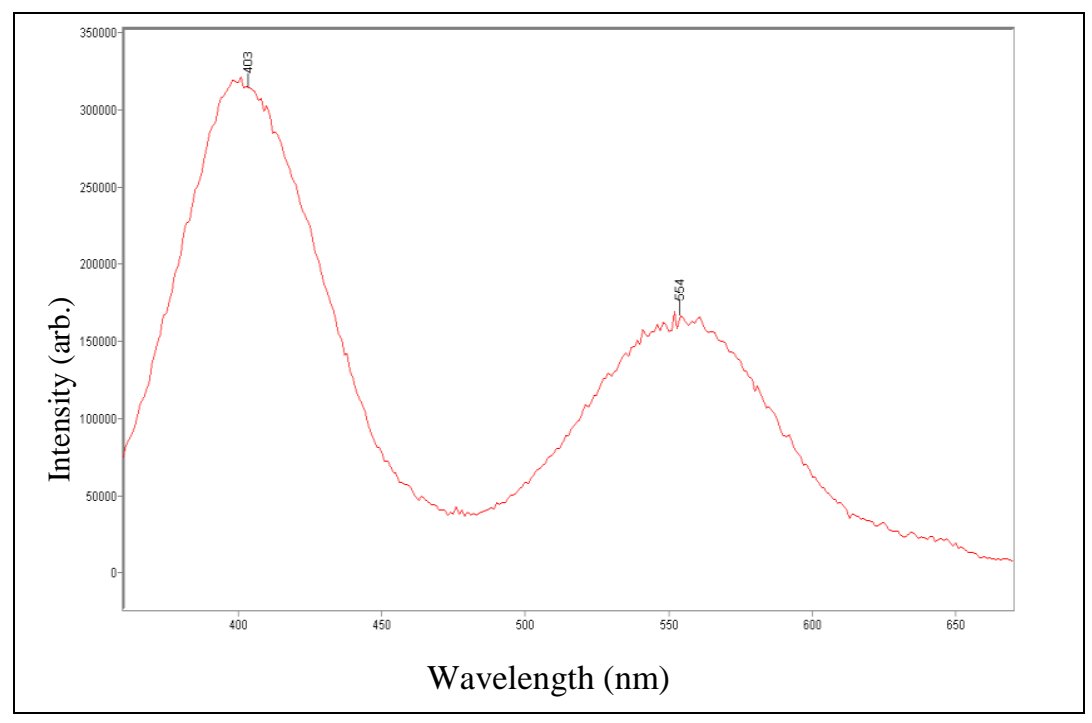

Figure 5. Excitation spectra of the ruby NPs

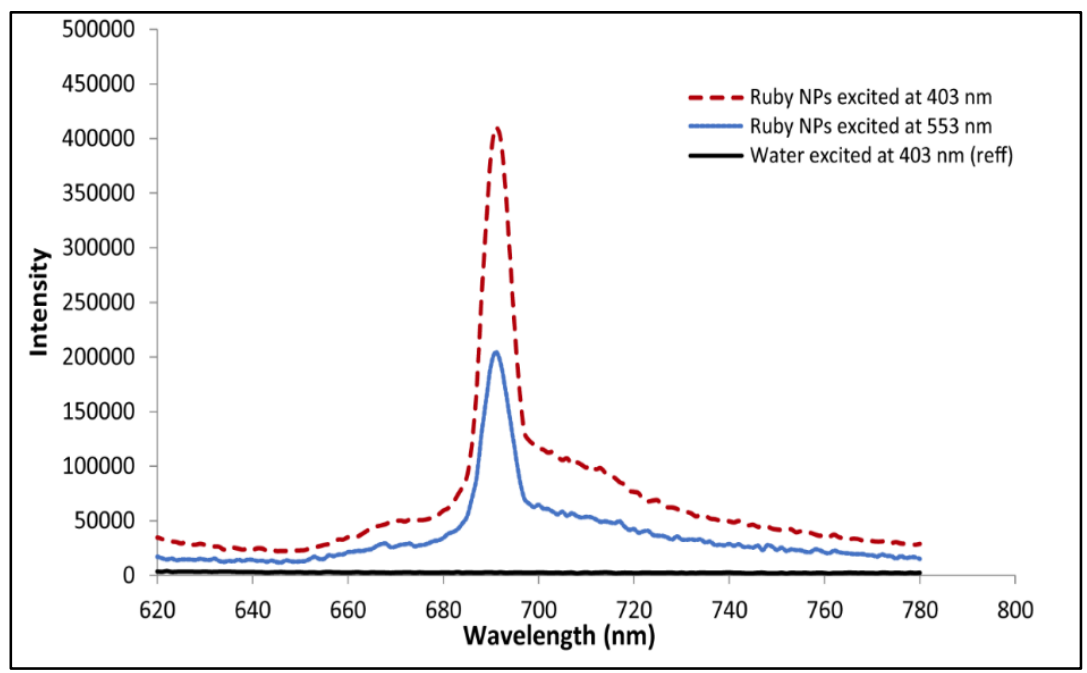

Figure 6. Emission spectrum of the ruby NPs colloid and distilled water

The image of Ruby NPs under $405 \mathrm{~nm}$ excitation is shown in Figure 6. Bright emission was observed using wide field microscope. These results clearly indicate the potential of the ruby NPs to be applied in bioimaging labelling in the future (Figure 7). 

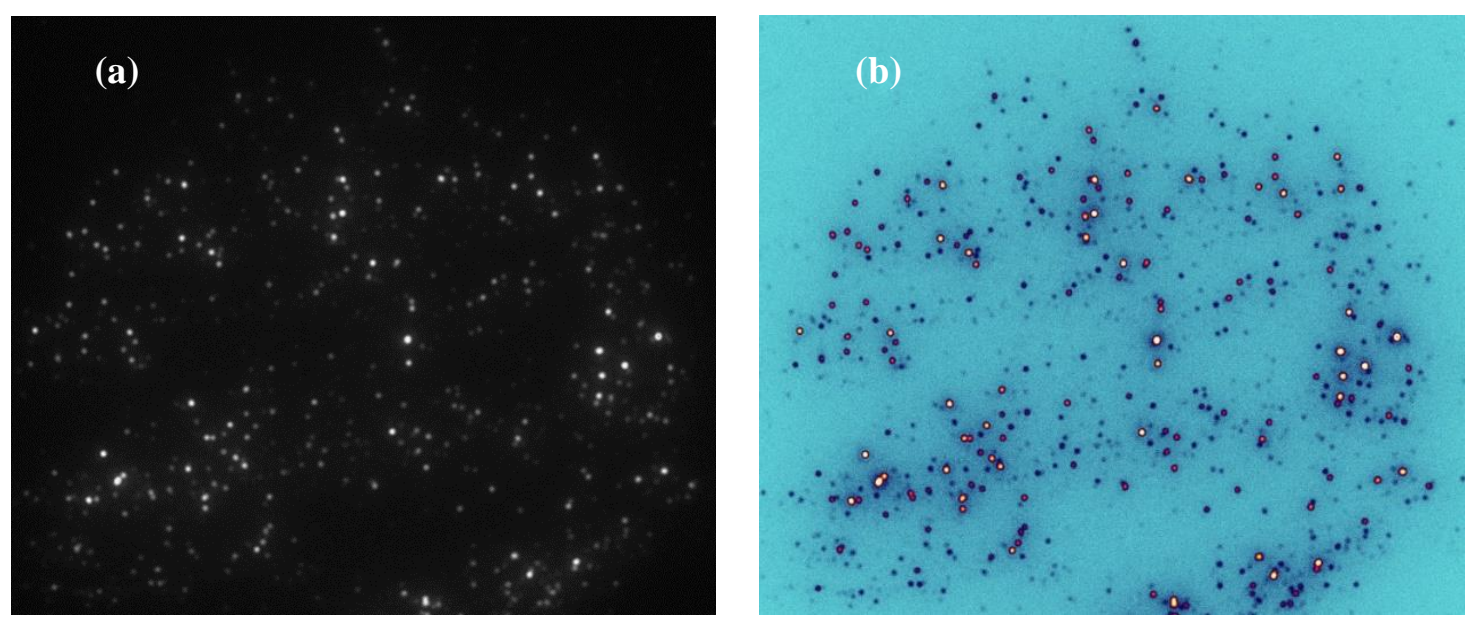

Figure 7. Image of ruby NPs under $405 \mathrm{~nm}$ excitation. Fluorescence image using wide field microscope (a) and (b) image after processing for clearer view

\section{Conclusion}

The physical and optical studies of prepared ruby NPs have been successfully discussed. The particle size was distributed from $50 \mathrm{~nm}$ to $120 \mathrm{~nm}$ centred at $52 \mathrm{~nm}$. TEM image illustrates the spherical shape of the particles. The excitation spectra of the ruby colloid show that the strongest absorption for the sample occurs at $405 \mathrm{~nm}$. Hence, the $554 \mathrm{~nm}$ excitation wavelength leads to the emission of red emission spectra centered at $690 \mathrm{~nm}$ which corresponding to the transitions of $\bar{E} \rightarrow^{4} \mathrm{~A}_{2}$ and $2 \bar{A} \rightarrow{ }^{4} \mathrm{~A}_{2}$. The outstanding properties of ruby NPs such as bright and sharp emission at $690 \mathrm{~nm}$ and excellent stability are potentially can be applied in biological labelling application.

\section{Acknowledgement}

The authors acknowledge financial support from Malaysian Government and University Teknologi MARA, and would like to acknowledge Macquarie University and University of Adelaide for their experimental equipment.

\section{References}

1. Maiman, T. H. (1960). Stimulated optical radiation in ruby. Nature, 187 (4736): 493-494.

2. Yang, L. Y., Dong, Y. J., Chen, D. P., Wang, C., Da, N., Jiang, X., Zhu, C. and Qiu, J. R. (2005). Upconversion luminescence from 2E state of $\mathrm{Cr}^{3+}$ in $\mathrm{Al}_{2} \mathrm{O}_{3}$ crystal by infrared femtosecond laser irradiation. Optics Express, 13 (20): 7893-7898.

3. Maiman, T. H. (1960). Optical and microwave-optical experiments in ruby. Physical Review Letters, 4 (11): 564-66.

4. Krizan, J., Mozina, J., Bajsic, I., and Mazaj, I. (2012). Synthesis and fluorescent properties of chromium-doped aluminate nanopowders. Acta Chimica Slovenica, 59(1):163-168.

5. Patra, A., Tallman, R. E. and Weinstein, B. A. (2005). Effect of crystal structure and dopant concentration on the luminescence of $\mathrm{Cr}^{3+}$ in $\mathrm{Al}_{2} \mathrm{O}_{3}$ nanocrystals. Optical Materials, 27(8): 1396-1401.

6. Schawlow, A. L., Wood, D. L. and Clogston, A. M. (1959). Electronic spectra of exchange-coupled ion pairs in crystals. Physical Review Letters, 3(6): 271-273.

7. Mollenauer, L. F. and Schawlow, A. L. (1968). Piezospectroscopic studies of exchange-coupled $\mathrm{Cr}^{3+}$ ion pairs in ruby. Physical Review, 168 (2): 309-317.

8. Kisliuk, P., Chang, N. C., Scott, P. L. and Pryce, M. H. L. (1969). Energy levels of chromium ion pairs in ruby. Physical Review, 184(2): 367-374.

9. Van der Ziel, J. P. (1974). Spectrum of first-nearest-neighbor $\mathrm{Cr}^{3+}$ pairs in ruby. Physical Review B, 9(7): 28462862. 
10. Engstrom, H. and Mollenauer L. F. (1973). Chronospectroscopy of exchange-coupled $\mathrm{Cr}^{3+}$-ion pairs in ruby. Physical Review B, 7 (4): 1616-1626.

11. Piriyawong, V., Thongpool, V., Asanithi, P. and Limsuwan, P. (2012). Effect of laser pulse energy on the formation of alumina nanoparticles synthesized by laser ablation in water. Procedia Engineering, 32: 11071112.

12. Rahman I. A. and Padavettan, V. (2012). Synthesis of silica nanoparticles by sol-gel: Size-dependent properties, surface modification, and applications in silica-polymer nanocomposites - a review. Journal of Nanomaterials, 2012 (8): 1-15.

13. Jaworek, A. (2007). Micro- and nanoparticle production by electrospraying. Powder Technology, 176(1): 18-35.

14. Mueller, R., Mädler, L. and Pratsinis, S. E. (2003). Nanoparticle synthesis at high production rates by flame spray pyrolysis. Chemical Engineering Science, 58(10): 1969-1976.

15. Iwamoto, M., Kuroda, K., Zaporojtchenko, V., Hayashi, S. and Faupel, F. (2003). Production of gold nanoparticles-polymer composite by quite simple method. The European Physical Journal D - Atomic, Molecular, Optical and Plasma Physics, 24(1): 365-367.

16. Nakaso, K., Han, B., Ahn, K. H., Choi, M. and Okuyama, K. (2003). Synthesis of non-agglomerated nanoparticles by an electrospray assisted chemical vapor deposition (ES-CVD) method. Journal of Aerosol Science, 34(7): 869-881.

17. Lam, C., Zhang, Y. F., Tang, Y. H., Lee, C. S., Bello, I. and Lee, S. T. (2000). Large-scale synthesis of ultrafine Si nanoparticles by ball milling. Journal of Crystal Growth, 220(4): 466-470.

18. Sajti, C., Sattari, R., Chichkov, B. and Barcikowski, S. (2010). Ablation efficiency of $\alpha-\mathrm{Al}_{2} \mathrm{O}_{3}$ in liquid phase and ambient air by nanosecond laser irradiation. Applied Physics A, 100(1): 203-206.

19. Liu, D. (2013). Effects of Cr content and morphology on the luminescence properties of the Cr-doped alpha$\mathrm{Al}_{2} \mathrm{O}_{3}$ powders. Ceramics International, 39(5): 4765-4769. 